Interdisciplinary Studies of Complex Systems

No. 15 (2019) 47-57

(c) Т. Глушко, Н. Мозгова

https://doi.org/10.31392/iscs.2019.15.047

\title{
ФІЛОСОФСЬКО-ЕКОНОМІЧНИЙ ДИСКУРС В УМОВАХ РОЗВИТКУ ЦИФРОВОЇ ЕКОНОМІКИ
}

\author{
Тетлна Глушко ${ }^{1,2}$, Наталія Мозгова ${ }^{1,3}$
}

\begin{abstract}
Анотація. Запропоновано системний аналіз феномену філософськоекономічного дискурсу, як важливого міждисциплінарного напряму, у контексті його структурних та смислових трансформацій в умовах сучасного етапу розвитку цивілізації. Актуалізовано потребу вдосконалення економічної культури суспільств, що розвиваються, основний акцент зроблено на проблемах сучасного українського суспільства.
\end{abstract}

Ключові слова: філософія економіки, дискурс, цифрова економіка, четверта промислова революція, інновації, людський капітал, економічна культура

\section{PHYLOSOPHICAL-ECONOMIC DISCOURSE UNDER DEVELOPMENT OF THE DIGITAL ECONOMY}

\author{
Tetyana Glushko, Nataliia Mozgova
}

\begin{abstract}
The article is devoted to the system analysis in such important cross-disciplinary branch as philosophy-economic discourse in its structural and meaningful transformations in conditions of contemporary civilization. Especially stressed on the need for improve an economic culture in developing societies, the main focus is on the appropriate problems in modern Ukrainian society.

Keywords: philosophy of economy, discourse, digital economy, the fourth revolution, innovation, human capital, economic culture
\end{abstract}

\section{Вступ}

Актуальність дослідження. В умовах сучасного світу актуалізується потреба вдосконалення методології економічної науки, яка на теоретичному рівні здебільшого все ще занурена у вимір парадигмального осмислення індустріальної ери. Сучасний же етап технологічного розвитку демон-

\footnotetext{
${ }^{1}$ Національний педагогічний університет імені М. П. Драгоманова, Київ, Україна.

2 tetyana.glushko@gmail.com, https://orcid.org/0000-0002-8759-7975.

3 mozgova@gmail.com, https://orcid.org/0000-0001-9464-9852.
} 
струє потребу трансформації економічного мислення з урахуванням паритету індустріальної та цифрової економік, адже остання розвивається досить швидкими темпами, пропонуючи світові все більше проривних інновацій, які змінюють соціально-економічні реалії на глобальному рівні. Закономірно виникає потреба вдосконалення економічних моделей у межах окремих соціальних систем, адже абстрактні моделі «вільного ринку» хоча й зберігали свою легітимність досить тривалий час, проте остаточно їі втратили з появою затяжної фінансової кризи глобального масштабу. Сучасний пост-ліберальний світ потребує більш специфічних та ефективних соціально-економічних стратегій, які будуть придатними для ефективного розвитку окремих країн та регіонів і враховуватимуть зміну парадигми, що пов'язана з революційними трансформаціями у сфері розвитку технологій. 3 цих позицій дослідження міждисциплінарного філософськоекономічного дискурсу набуває особливої актуальності саме у руслі визначення підходів для формування нових продуктивних економічних стратегій, особливо для суспільств, що розвиваються та суттєво відстають від глобальних тенденцій.

Мета статті - проаналізувати основні структурні виміри та перспективні напрями трансформації сучасного філософсько-економічного дискурсу, визначити принципи ефективізації національних економічних стратегій в умовах формування нового технологічного укладу відомого під загальною назвою четвертої промислової революції, що спричинена появою та розвитком цифрової економіки.

Стан наукового опрацювання проблеми. Цифрова економіка, як принципово новий вимір соціальної інтеграції на основі досягнень новітніх технологій, є предметом дослідження економістів, соціологів та філософів. Цей феномен вперше був описаний у роботі канадського дослідника Д. Тапскотта «Цифрова економіка: обіцянки та небезпеки в епоху мережевого інтелекту», що побачила світ 1995 року [див. 17]. У такий спосіб було здійснено постановку проблеми щодо формування принципово нового соціально значимого феномену, що поступово змінював стратегії економічної взаємодії не лише локально, а й глобально. Власне, дослідження філософських засад цифрової економіки притаманне здебільшого євроатлантичній традиції, зокрема важливими у даному напрямі $є$ роботи Е. Шмідта та Д. Коена, а саме їх дослідження, що присвячене «новому цифровому світові», а також аналітична розвідка щодо феномену четвертої промислової революції, здійснена основоположником всесвітнього економічного форуму у Давосі К. Швабом. Досить продуктивним є дослідження американського аналітика А. Росса, що присвячене індустріям майбутнього у їх зв'язку 3 розвитком цифрових технологій. Критичний аналіз так званого цифрового капіталізму здійснено у дослідженнях М. Бетанкура [див. 13], феномен праці та трансформації параметрів її капіталізації у цифровому світі досліджено у роботах британської дослідниці У. Хьюз [див. 15]. Міжлисциплінарні дослідження у галузі взаємозв'язку державної політики та цифрової економіки здійснюють К. Холройд та К. Коутс [див. 14]. Актуальні дослідження у галузі розвитку криптовалют та блокчейн-революції реалізовані 
такими авторами як Д. Тапскотт, Н. Поппер [див. 7], П. Вінья, М. Кейсі [див. 3] та інші. В українському науковому просторі з концептом «цифрової економіки» здебільшого працюють дослідники-економісти, а основною метою таких аналітичних розвідок $є$ можливості та перешкоди для ефективної імплементації окремих здобутків сучасної цифрової економіки на теренах нашої країни.

Наукова новизна дослідження полягає у тому, що вперше запропоновано комплексний аналіз феномену філософсько-економічного дискурсу у його актуальних для сучасності проявах, а саме його провідних структурних векторів, що актуалізуються на рівні розвитку новітніх тенденцій в економічній площині життєдіяльності суспільств та вимагають осмислення їх соціально-конструктивного потенціалу.

Методологія дослідження сучасного філософсько-економічного дискурсу з позицій аналізу його основних структурних рівнів та перспектив їх впливу на глобальні трансформації в економічних процесах передбачає використання методу структурного аналізу для виявлення ключових елементів соціально-економічного континууму, що потребують переосмислення та грунтовного філософського аналізу у контексті їх впливу на підвищення якості національних економічних стратегій; метод синтезу для їх системного узагальнення й постулювання цілісного бачення недоліків та переваг економічної культури сучасного українського суспільства у сфеpi розвитку цифрової економіки, як важливого структурного компонента ефективної господарської системи.

\section{Походження та характеристика сучасного економічного дискурсу}

Постмодерний етап розвитку цивілізації актуалізував дискурсивний підхід до дослідження соціальної реальності. Не оминула ця тенденція й спеціальні наукові галузі, що сприяло як появі міждисциплінарних досліджень, так й утвердженню методологічного плюралізму у межах сфери впливу постнекласичної наукової раціональності. Однією з таких кроссдициплінарних галузей стала філософія економіки, що у якості самостійного напряму сформувалася у другій половині минулого століття. Сьогодні аналітика економічних процесів з позиції доповнення та вдосконалення класичних підходів засобами впровадження специфічної філософської методології сформувала досить потужний, структурно диференційований спектр дослідницької активності у цій галузі.

Економічна наука у класичному своєму варіанті сформувалася у вимірі морально-філософських пошуків А. Сміта, котрий намагався виявити основні механізми та закономірності функціонування такого феномену як ринок, зокрема зв'язку таких його елементів як попит та пропозиція. Економічний же дискурс наприкінці XX - початку XXI століття набув значно складніших форм та структур як за рахунок його більш суттєвої математизації, так й за рахунок нагромадження змістовно різнорідних концепцій та теорій. Сучасна економіка являє собою своєрідний синтез математичних 
моделей та формул, з одного боку, та систему соціально-гуманітарних світоглядних конструкцій - 3 іншого.

Таким чином, сучасна економічна теорія включає в себе не тільки множину методологічно різнорідних теорій і концепцій, що сформувались історично, а й досить відчутну динаміку смислових структур у вимірі протистояння та взаємодії глобально й національно орієнтованих економічних стратегій, що передбачають конституювання основних сценаріїв глобалізації та її економічних векторів [див. 6]. Разом з тим, сам процес глобалізації якраз значною мірою й став можливим завдяки розвиткові інформаційних технологій, та, по суті, спричинив появу цифрової економіки, що на сучасному етапі стає домінуючим елементом розвинених економічних систем.

Відповідно, сучасний дискурс не може ігнорувати той спосіб мислення, що необхідний для подальшого продуктивного розвитку нового рівня економічних інтеракцій. Тоді як домінуюче у пострадянському просторі економічне знання поки що лише частково $є$ продуктом цифрового дискурсу, адже досить незначний сегмент ринку працює у відповідному секторі. Тенденції ж розвитку глобальної економічної культури демонструють провідну роль та першорядне значення саме технологічного сектору економічних систем.

Так, за визначенням К. Шваба, новий революційний етап у промисловості спирається саме на цифрову революцію і пов'язаний з розвитком мережі Інтернет та її майбутніми перспективами, такими як цифрові технології (повна автоматизація виробництва, Інтернет речей, робототехніка тощо) та стратегії роботи над створенням штучного інтелекту [див. 11], що 3 необхідністю будуть спричиняти трансформацію господарських систем як окремих суспільств, так і глобальної економіки в цілому. Таким чином, кардинальні системні трансформації та швидкі темпи розвитку сучасних технологій, а також їхній глобальний вплив на господарські процеси, вимагають формування принципово нових, інноваційних відгуків на рівні сучасних національних та регіональних економік.

\section{Соціально-практичне значення філософсько-економіч- ного дискурсу}

Узагальнюючи стратегічний досвід сучасних пострадянських країн, на наш погляд, структурно варто визначити своєрідний бінарний стратегічний код, тобто виокремити два стратегічні вектори. Фактично усі національні чи регіональні економічні стратегії, незалежно від їх конкретнозмістовного наповнення, умовно варто розділити на дві групи. Йдеться, по-перше, про «стратегію ескапізму» як своєрідну втечу від викликів сучасного світу та непродуктивне відтворення узвичаєних поведінкових паттернів та, по-друге, «стратегію пошуку ефективних альтернатив», яка передбачає не пасивно-пристосовницький, а творчо-активний підхід до трансформації соціально-економічних процесів.

Так, сучасному українському суспільству протягом останніх двох з половиною декад характерна якраз стратегія економічного ескапізму, основні стратегеми якої орієнтовані на втілення політики фінансового кредитування з боку міжнародних донорів та не надто ефективне використання цих 
коштів. Такий підхід дозволяє створювати ілюзію економічного зростання та фальшувати економічну статистику. Адже, здебільшого сировинна економіка сучасної України та відсутність потужного виробничого сектору, а також фрагментарне використання переваг цифрової революції, не створює сприятливих умов для продуктивного розвитку національної економіки. Тоді як в умовах глобалізованого світу економічний націоналізм продовжує відгравати важливу роль, що й демонструє не лише історія розвитку провідних країн євроатлантичного регіону, а й їхня сучасність [див. $4 ; 8]$.

На підвищення ефективності національних економік розвинених країн та їх технологічних секторів працює й відсутність активних стратегій у більшості країн, що розвиваються. Як влучно відзначає російський дослідник В. Сологубов, країни, які потрапили у боргову залежність, вимушені скорочувати видатки на соціальні потреби, тобто на освіту, охорону здоров'я та зайнятість, що з необхідністю призводить до зниження рівня матеріального забезпечення та до культурної деградації [див. 10, с. 93], а отже й не створює сприятливих умов для розвитку інновацій. Крім того, синтез недостатньої економічної та фінансової освіченості населення, а також корумпованості чиновників, створює ще більш несприятливі інституційні умови для розвитку продуктивного технологічного сектору економіки, а відповідно, й для більш ефективного управління соціально-економічними процесами всередині країни.

Власне проблема управління державним багатством якраз і постає як «один з найважливіших інституційних елементів, за яким країни з ефективним устроєм відрізняються від неспроможних держав» [5, с. 24]. До того ж, дійсно ефективне управління можливе у разі забезпечення не лише необхідних когнітивно-раціональних умов як то знання принципів ефективізації національного економічного простору чи розуміння механізмів їх впровадження, а й за умови конституювання відповідної аксіологічної основи з настановою на спільне благо, що, звісно, є принципово різними рівнями освоєння економічної культури в цілому та поточної ситуації зокрема. Відповідно, колективна робота національних економічних еліт не лише на власний добробут, а й на інтереси своєї країни є важливим елементом впровадження більш ефективних соціально-економічних стратегій.

Основними чинниками підвищення економічної ефективності $є$ не перерозподіл наявного, ресурсного «багатства», а створення додаткової вартості, тобто імпорт не сировини, а готової продукції, в тому числі й інтелектуальної. Структура ж економічних відносин та соціальних інститутів у сучасній Україні не сприяє реалізації її людського капіталу. Західні дослідники наголошують, що Україна дійсно могла б займати провідне місце у світі за рівнем розвитку технологій та високотехнологічних компаній, звісно, за умови «якби створила функціональне середовище для інновацій» [9, с. 241], адже «серед країн Центральної і Східної Європи Україна є основним джерелом, звідки відбувається залучення зовнішніх ресурсів для послуг в інформаційно-технологічній сфері» [9, с. 240]. Цілком закономірно, що відсутність ефективних інституційних умов для реалізації людського капіталу в межах нашої країни спричиняє суттєвий його відтік за кордон. 
Разом з тим, на сучасному етапі на новий рівень виходить доба цифрових платежів, внаслідок чого інноваційні технології найближчим часом можуть кардинально змінити структуру світової системи господарювання у сфері комерційних та банківських процесів й створити глобальну інтегровану цифрову економіку. Революційна технологія програмування грошей створює потенційні умови для радикальної трансформації економічної практики з часів появи банку у якості соціального інституту, що відбулось в Італії в епоху Відродження під патронатом сім’ї Медічі [див. 3]. Сучасна ж цифрова революція декламує можливість усунення банків у якості посередників у фінансовій діяльності індивідів, пропонуючи нову фінансову технологію (блокчейн), продуктом якої стали так звані криптовалюти, тобто цифрові гроші, технологічне забезпечення яких не передбачає таких соціально-економічних феноменів як інфляція, корупція чи фінансова криза, що характерні для традиційних фінансових систем.

Як бачимо, у вимір альтернативних економічних процесів поступово переходить увесь сучасний розвинений світ, тому, так чи інакше, український соціум муситиме пройти як через трансформацію економічної поведінки, так й економічного мислення. Адже високотехнологічні сектори економіки, по суті, є однією з найважливіших тенденцій, яка змінює саме розуміння економічних процесів та їх сутнісних вимірів. Громадяни «цифрового світу» для успішності та конкурентоздатності мають зважати, що відбувається трансформація провідних способів взаємодії суб'єктів господарської діяльності та змінюється спосіб виробництва, з'являються нові індустрії та нові бізнес-моделі. У такий спосіб, відбувається суттєва трансформація та оновлення усього «тіла економіки», ігнорувати які сировинним економічними системами стає дедалі складніше.

Втрата ж можливості ефективно ввійти у сферу структурних перетворень нової, альтернативної моделі економічних процесів, може спричинити остаточне закріплення за країною статусу сировинного придатку. Тому цифрова трансформація економіки на рівні національних господарських процесів $є$ сьогодні хоч і надскладним, але й надважливим завданням для країн, які все ще перебувають на етапі розвитку свого економічного потенціалу та не сформували власної «ніші» у структурі глобальних економічних перетворень.

Усвідомлення змін, що відбуваються та впровадження засобів управління ними як у напрямі розсіювання фінансової влади еліт, так й формування нових технологічних проривів, що сприятимуть підвищенню ефективності економіки та прискорюватимуть накопичення суспільного багатства, для пострадянських суспільств $є$ першорядним соціально-практичним завданням як на рівні суто економічних, так і соціально-філософських досліджень.

Прагматичною потребою будь-якого суспільства, що розвивається у сучасних умовах, є формування продуктивного відгуку на виклики четвертої промислової революції [див. 11], що, дійсно, не можуть бути реалізовані у позаінноваційному форматі. Як влучно відзначає А. Росс, «не можна підготуватися до майбутнього, зробивши подвійну ставку на минуле» [9, с. 52]. Інновація ж, як досить складний соціальний процес, потребує осмисленого аналізу потреб та можливостей суспільства, а також пошуку джерел для 
економного прориву у новому високотехнологічному світі, якому характерні кардинальні системні зміни у структурі економічних процесів.

Досить вдало властиву сучасному українському суспільству ситуацію ілюструє наступна метафора: «у час, коли хай-тек підприємці заново винаходять світ, розробники державної політики заново винаходять колесо» $[5$, с. 15]. Влучність такої метафори складно не визнати, враховуючи, що економічна політика більшості сучасних пострадянських країн та регіонів все ще орієнтується на стандарти індустріального світу значно більшою мірою, ніж на будь-які інші. Тоді як «суттєво посилили свої позиції окремі особи й країни, які зуміли зловити хвилю технологічних інновацій» $[9$, с. 18]. Які ж умови потрібно створити в Україні, щоб її технологічно-креативний потенціал працював на перспективу самої країни?..

Перш за все, творення економіки на основі інновацій, тобто створення умов для соціальних інноваторів, передбачає серйозний підхід до трансформації соціальних інститутів [див. 1], адже хибні орієнтири розвитку, дійсно, ведуть у глухий кут, тобто тільки до посилення економічної нестабільності, що ми й спостерігаємо протягом останніх років. Створення економічно стабільнішого способу життя вимагає формування нового господарського укладу та нової моделі створення багатства, ніж та, що характерна сучасному українському суспільству.

Крім того, поступове становлення інновацій у фінансовій системі передбачає також й нову модель капіталізації часу працівників. Тому перехід до більш життєздатної моделі економічного розвитку, що задовольнятиме потреби суспільства, до більш прогресивної економіки, вимагає подолання інтенцій сучасного непродуктивного періоду та формування нових «правил гри», в тому числі у сфері домінуючого аксіологічного та моральноетичного дискурсу в економіці.

В умовах становлення нового економічного укладу та відповідної йому мисленнєвої парадигми існує також суттєва можливість збереження опозиційності національних та глобальних економічних стратегій, принаймні до остаточного затвердження за регіонами окремих секторів та економічних кластерів: «державні установи та приватні компанії з усього світу змагатимуться за шанс постачати свою продукцію та послуги країнам, які їх прагнуть» [12, с. 117]. Тому продуктивний розвиток економічної системи передбачає стратегічний супровід у сфері впровадження конкурентоздатних стартапів і соціальних інновацій та відповідної їм культури економічного мислення. Таким чином, домінуюче протягом кількох останніх десятиліть «суспільство споживання» мусить трансформуватися у суспільство творців-інноваторів, що вимагатиме впровадження альтернативних економічних стратегій соціального розвитку.

\section{Філософсько-економічний дискурс в освіті}

Формування нового технологічного укладу, тобто новий цикл цивілізаційного поступу, передбачає, як бачимо, якісне перетворення структур глобальної економічної системи. Відповідно, четверта промислова революція, як радикальна зміна економічного укладу на рівні глобальних перетворень, передбачає й появу нових виробничих технологій та нових ринків. 
Останні ж, в свою чергу, модифікують зміст та змінюють форми навчання, тобто спричиняють потребу трансформації освітніх програм, особливо зважаючи на формування нових тенденцій у сфері зайнятості. Зокрема йдеться про потребу «реформувати систему освіти, щоб більше студентів реалізувало себе в культурі інновацій» [12, с. 284]. Особливо важливою ця потреба виглядає з огляду на зміну поколінь та появу так званого «покоління Z» або digital natives, тобто «цифрових аборигенів».

Згідно класифікації, запропонованої американськими дослідниками В. Штраусом та Н. Хоувом міждисциплінарної теорії поколінь, циклічна зміна останніх відбувається за рахунок їхньої приналежності до різних ціннісних систем, які визначають їх особистісне становлення, що й спричиняє так звані конфлікти поколінь [див. 16]. Так от, сучасне «цифрове покоління», за прогнозами дослідників, вже найближчим часом змінить ігрове поле світової економіки, як тільки масово вийде на ринок праці. Цінності та настанови цього покоління сформовані у інтерактивному середовищі цифрової культури, а їхні освітні потреби суттєво відрізняються від потреб попередніх поколінь. Змінюється формат сприйняття та засвоєння інформації, а тому традиційні освітні підходи, які були дієвими для двох попередніх поколінь, фактично виявляються низькоефективними для сучасного.

Процес формування у нового покоління інтегративного економічного мислення, як здатності охоплювати всю багатоаспектність конкретної проблеми та множини шляхів 前 вирішення, в тому числі й в руслі застосування до її аналізу нестандартних підходів, передбачає формування у сфері викладання економіки нової педагогічної культури, орієнтованої на так зване проектне мислення. Специфіка останнього полягає в тому, що воно «починається із припущення, що вирішення питання можливе у будьякому разі, незважаючи на рівень складності проблеми» [2, с. 25]. Саме такий підхід до розв'язання комплексних економічних проблем, що накопичувалися в українському суспільстві досить тривалий час, дозволить, на наш погляд, створювати більш креативні соціально-економічні програми та бізнес-стратегії, здійснювати більш ефективні реформи в економічному секторі, впроваджуючи інноваційні продукти, послуги та ідеї.

Ще одним важливим аспектом є напрям таких інновацій та їхньої собівартості. Зокрема, за А. Россом, сутність економічних інновацій полягає у здатності «генерувати ідеї нових корисних продуктів із низькою собівартістю й на основі обмежених матеріалів» [9, с. 29]. Таким чином, специфіка економічного мислення, здатного продукувати такі ідеї та розробляти на їх основі нові продукти, що мали б суттєвий попит, повинна, за визначенням, передбачати неабияку соціально-креативну компоненту.

Відповідно, освітні програми на рівні вищих навчальних закладів потребують суттєвих трансформацій - при чому не тільки на рівні форми подачі матеріалу та використання інтерактивних засобів, а й змістовно з урахуванням необхідності міждисциплінарного підходу, який визначатиме специфіку епохи - потребу у якісно новій інформації та у засобах її продуктивної аналітики в умовах світу, що швидко змінюється. Тому у вимірі сучасної економічної освіти така міждисцплінарність, на наш погляд, має бути задоволена шляхом впровадження якісно нових освітніх програм філософсько-економічного спрямування. 
Такі програми мають, з нашої точки зору, включати в себе не лише суто економічну інформацію (як то економічні концепції та теорії чи методи ïx конституювання), а й кейси та ігрові задачі з включенням фiлософсъкой компоненти як то, наприклад, обгрунтування системи цінностей суб'єктів економічної діяльності у конкретній ситуації чи обгрунтування ідеології країни або компанії, iï місця на глобальному та національному ринку, що власне передбачає формування такої компетенції як здатність до визначення практичного потенціалу економічних ідеологій у конкретних історичних умовах та на всіх рівнях їх функціонування.

Отже, зважаючи на вищевикладені зауваження, можемо підсумувати, що сучасний філософсько-економічний дискурс включає в себе цілий комплекс складних інтегративних проблем, що зумовлені не лише наслідками тривалої фінансової кризи, а й зміною технічного укладу, тобто активним розвитком четвертої промислової революції та відповідних трансформацій на рівні економічної свідомості сучасного світу в цілому та окремих суспільств зокрема, що супроводжуються зміною парадигми економічного мислення. Основними ж структурними рівнями розгортання філософськоекономічної проблематики на сучасному етапі $є$ проблема ефективного управління ресурсами та багатством суспільств, слабкі соціальні інститути, досить швидка трансформація ринку праці та становлення нових індустрій, проблема програмування фінансової сфери, а також стратегії ефективного впровадження інновацій. Нагальними для вирішення проблемами на рівні національних економік країн, що розвиваються, є орієнтація не тільки на стандарти індустріального технічного укладу, а випрацювання паритету між індустріальним та цифровим вимірами економічної активності. Зокрема для сучасної України важливо здійснити 1) формування та впровадження альтернативної стратегії соціально-економічного розвитку, що передбачатиме становлення потужного виробничого сектору та максимальне використання потенційних переваг сучасних цифрових технологій; 2) продуктивне реформування соціальних інститутів у напрямі сприяння розвиткові start-up-культури на рівні малого та середнього бізнесу, що $є$ базисом для розвитку ефективної економічної системи; 3) впровадження міждисциплінарних освітньо-практичних програм філософсько-економічного спрямування, орієнтованих на підготовку фахівців якісно нового рівня 3 відповідною аксіологічною базою та системою компетенцій, придатних для ефективного вирішення комплексних соціально-економічних задач в умовах цифрової трансформації економічних процесів.

\section{Література}

[1] Аджемоглу, Д. та Робінсон Д. 2016. Чому нацї̈ занепадають. Походження влади, багатства та бідності / пер. з англ. О. Дем'янчука. Київ : Наш Формат.

[2] Вагнер, Т. 2015. Створення інноваторів: як виховати молодъ, яка змінить світ : пер. $з$ англ. Київ: K.FUND.

[3] Винья, П. та Кейси М. 2017. Эпоха криптовалют. Как биткоин и блокчейн меняют мировой экономический порядок / пер. Эльвира Кондукова. Москва: Манн, Иванов и Фербер. 
[4] Глушко, Т. П. 2015. Економічна теорія націӥ: соціально-філософсъкий контекст: монографія. Київ: Видавництво університету імені М.П. Драгоманова.

[5] Деттер, Д. та Фьольстер С. 2017. Державне багатство народів. Як управління державними активами може посилити чи підірвати економічне зростання / пер. з англ. Ірини Піонтківської. Львів: Видавництво Старого Лева.

[6] Зубкевич, Л. А. 2015. Сущность глобализации и её сценарии. Beстник ВГУ. Серия: Философия, 2:58-70 http://www.vestnik.vsu.ru/ pdf/phylosophy/2015/02/2015-02-04.pdf

[7] Поппер, Н. 2016. Цифровое золото. Невероятная история Биткоина или о том, как идеалисты и бизнесмены изобретают денъги заново / пер. с англ. А. Барабаш. Москва: Вильямс.

[8] Райнерт, Э. 2011. Как богатые страны стали богатыми, и почему бедные страны остаются бедными / пер. с англ. Н. Автономовой; под ред. В. Автономова. Москва: Изд. дом Гос. ун-та Высшей школы экономики.

[9] Росс, А. 2017. Індустрії майбутнъого / пер. з англ. Наталія Кошманенко. Київ: Наш формат.

[10] Сологубов, В. М. 2011. Природа финансовых кризисов. Філософiя фiнансової иивілізаціӥ: людина у світі грошей: матеріали IV Міжнародних філософсько-економічних читань (18-20 травня 2011 року) / Відп. секретар 3.С. Скринник. Львів, 87-93.

[11] Шваб, К. 2017. Четвертая промышленная революция : пер. с англ. Москва: Эксмо.

[12] Шмідт, Е. та Коен Дж. 2015. Новий цифровий світ / пер. $з$ англ. Ганна Лелів. Львів : Літопис.

[13] Betancourt, M. 2015. The Critique of Digital Capitalism: An Analysis of the Political Economy of Digital Culture and Technology. New York: Punctum Books.

[14] Holroyd, C. and Coates K. S. 2015. The Global Digital Economy: A Comparative Policy Analysis. New York: Cambria Press.

[15] Huws, U. 2014. Labor in the Global Digital Economy: The Cybertariat Comes of Age. New York: Monthly Review Press.

[16] Strauss, W. and Howe N. 1997. The Fourth Turning: an American Prophecy. The First Edition. New York: Broadway Books.

[17] Tapscott, D. 2015. The Digital Economy: Promises and Perils in the Age of Networked Intelligence. 20th Anniversary Edition. New York: McGrawHill.

\section{References}

[1] Adzhemohlu, D. ta Robinson D. 2016. Chomu natsii zanepadaiut. Pokhodzhennia vlady, bahatstva ta bidnosti / per. z anhl. O. Dem'ianchuka. Kyiv : Nash Format.

[2] Vahner, T. 2015. Stvorennia innovatoriv: yak vykhovaty molod, yaka zminyt svit : per. $\mathrm{z}$ anhl. Kyiv: K.FUND. 
[3] Vinya, P. ta Keysi M. 2017. Epoha kriptovalyut. Kak bitkoin i blokcheyn menyayut mirovoy ekonomicheskiy poryadok / per. Elvira Kondukova. Moskva: Mann, Ivanov i Ferber.

[4] Hlushko, T. P. 2015. Ekonomichna teoriia natsii: sotsialno-filosofskyi kontekst: monohrafia. Kyiv: Vydavnytstvo universytetu imeni M.P. Drahomanova.

[5] Detter, D. ta Folster S. 2017. Derzhavne bahatstvo narodiv. Yak upravlinnia derzhavnymy aktyvamy mozhe posylyty chy pidirvaty ekonomichne zrostannia / per. z anhl. Iryny Piontkivskoi. Lviv: Vydavnytstvo Staroho Leva.

[6] Zubkevich, L. A. 2015. Suschnost globalizatsii i eYo stsenarii. Vestnik VGU. Seriya: Filosofiya, 2:58-70 http://www.vestnik.vsu.ru/pdf/phylosophy/2015/02/2015-02-04.pdf

[7] Popper, N. 2016. Tsifrovoe zoloto. Neveroyatnaya istoriya Bitkoina ili o tom, kak idealistyi i biznesmenyi izobretayut dengi zanovo / per. s angl. A. Barabash. Moskva: Vilyams.

[8] Raynert, E. 2011. Kak bogatyie stranyi stali bogatyimi, i pochemu bednyie stranyi ostayutsya bednyimi / per. s angl. N. Avtonomovoy; pod red. V. Avtonomova. Moskva: Izd. dom Gos. un-ta Vyisshey shkolyi ekonomiki.

[9] Ross, A. 2017. Industrii maibutnoho / per. z anhl. Nataliia Koshmanenko. Kyiv: Nash format.

[10] Sologubov, V. M. 2011. Priroda finansovyih krizisov. Filosofiia finansovoi tsyvilizatsii: liudyna u sviti hroshei: materialy IV Mizhnarodnykh filosofskoekonomichnykh chytan (18-20 travnia 2011 roku) / Vidp. sekretar Z. S. Skrynnyk. Lviv, 87-93.

[11] Shvab, K. 2017. Chetvertaya promyishlennaya revolyutsiya : per. s angl. Moskva: Eksmo.

[12] Shmidt, E. ta Koen Dzh. 2015. Novyi tsyfrovyi svit / per. z anhl. Hanna Leliv. Lviv : Litopys.

[13] Betancourt, M. 2015. The Critique of Digital Capitalism: An Analysis of the Political Economy of Digital Culture and Technology. New York: Punctum Books.

[14] Holroyd, C. and Coates K. S. 2015. The Global Digital Economy: A Comparative Policy Analysis. New York: Cambria Press.

[15] Huws, U. 2014. Labor in the Global Digital Economy: The Cybertariat Comes of Age. New York: Monthly Review Press.

[16] Strauss, W. and Howe N. 1997. The Fourth Turning: an American Prophecy. The First Edition. New York: Broadway Books.

[17] Tapscott, D. 2015. The Digital Economy: Promises and Perils in the Age of Networked Intelligence. 20th Anniversary Edition. New York: McGrawHill. 